\title{
Kultur Sekolah
}

Oleh

\section{Ariefa Efianingrum ${ }^{1}$}

\begin{abstract}
Abstrak
Tulisan ini hendak mengelaborasi sejumlah pemikiran dan konsep yang meyakini pentingnya faktor kultural dalam mendorong dinamika perubahan institusional, khususnya dalam konteks persekolahan (schooling). Perlu tilikan secara seksama bahwa budaya/kultur merupakan kekuatan konstitutif untuk inovasi dan perubahan sosial, sekaligus memiliki kekuatan reflektif dalam melakukan peran legitimasi sosial.Kultur meliputi faktor material yang tangible dan non-material yang intangible. Realitas menunjukkan bahwa kunci keberhasilan pendidikan seringkali justru terletak pada faktor yang tak terlihat. Karenanya, menekankan perbaikan pendidikan di sekolah pada proses restrukturisasi semata, tidak lagi memadai. Namun demikian, restrukturisasi yang bersifat struktural dan rekonstruksi yang bersifat kultural tidak perlu saling menegasikan dalam praktiknya. Dalam pengembangan kultur sekolah, terdapat aneka pilihan alternatif yang dapat disesuaikan dengan visi-misi dan kondisi sekolah, serta profil siswa dalam aneka kecerdasan majemuk (multiple intelligences). Betapapun intervensi kebijakan pendidikan telah dilakukan, tidak akan memberikan efek bermakna, tanpa perubahan yang sifatnya kultural dari dalam institusi pendidikan itu sendiri. Dalam konteks sekolah yang berada dalam masyarakat paternalistik, pimpinan sekolah menjadi ikon yang memiliki peran utama dalam pengembangan kultur sekolah.
\end{abstract}

Kata kunci: pendidikan, budaya, kultur sekolah.

\begin{abstract}
This paper would like to elaborate some thoughts and concepts that consider the significances of cultural factors in promoting the dynamics of institutional changes, especially in schooling context. It is necessary to realize that a culture is a constitutional power for innovations and social changes as well as a reflective power for conducting social legitimation role. A culture involves tangible and intangible factors. In fact, intangible factors frequently become the keys for educational success. Therefore, it is not sufficient to emphasize the school improvements only in the structural processes. However, practically, restructuring and cultural reconstruction cannot negate each other. There are several alternatives in developing school culture, which can be adapted to the school visions-missions and the students multiple intellegences profiles. In giving meaningful impact, the educational policies are meaningless without cultural changes in the institution it self. Furthermore, in the context of paternalistic society, school principal as a leader becomes a main icon in developing school cutures.
\end{abstract}

Keywords: education, culture, school culture.

\section{A. Pendahuluan}

Proses dan aliran perubahan sosial dalam masyarakat membawa implikasi besar dalam dunia pendidikan. Hal ini karena keberhasilan pengembangan sektor pendidikan diyakini sebagai salah satu penentu kemajuan suatu bangsa. Pendidikan juga membawa misi kebajikan dan mencerdaskan kehidupanbangsa. Sebagaimana konsep pendidikan Tamansiswa yang sistem digagas oleh Ki Hadjar Dewantara, bahwa pendidikan

\footnotetext{
${ }^{1}$ Ariefa Efianingrum adalah staf pengajar di Fakultas Ilmu Pendidikan, Universitas Negeri Yogyakarta.
} 
merupakan sarana perjuangan kebudayaan dan pembangunan masyarakat. Pendidikan yang tidak disadari oleh kebudayaan akan menghasilkan generasi yang tercerabut dari kehidupan masyarakatnya (HB X, 2012).

Dalam konteks persekolahan (schooling), sekolah memiliki konsekuensi dan tantangan yang semakin berat, terkait dengan tuntutan masyarakat terhadap kualitas dan layanan pendidikan yang seharusnya diberikan. Sekolah dipercaya sebagai institusi yang menjadi arena pengembangan aneka potensi dan kecerdasan majemuk siswa (multiple intelligences). Oleh karena itu, upaya perbaikan sekolah perlu didorong menjadi aktivitas yang melekat (embedded) dalam setiap gerak perubahan sekolah. Dalam membangun pendidikan di sekolah, terdapat dua wacana besar:

"Wacana pertama adalah $\begin{array}{r}\text { academic } \\ \text { achievement discourses }\end{array}$
pengembangan prestasi akademik), sebagai
wacana dominan yang lebih menekankan
pada proses restrukturisasi (meliputi:
deregulasi, desentralisasi, perubahan
kurikulum, dan pelatihan). Sedangkan
wacana yang kedua adalah wacana kultural
yang lebih menekankan pada aspek
rekonstruksi (terkait dengan redefinisi,
rekulturasi, dan pergeseran mind-sets)"

(Suyata, 2000).

Pernyataan tersebut bermakna bahwa menekankan perbaikan pendidikan hanya pada proses restrukturisasi, tidak lagi memadai, mengingat adanya keyakinan bahwa sistem sosial dan sistem budaya menjadi medan dan kunci keberhasilan pendidikan. Kunci keberhasilan pendidikan seringkali justru terletak pada faktor-faktor yang tidak teramati (intangible) seperti nilai-nilai budaya dan keyakinan. Namun, faktor kultur tersebut seringkali terabaikan dalam upaya perbaikan pendidikan. Berkaitan dengan pendapat tersebut, pendapat yang lain mengemukakan adanya dua pendekatan dalam perubahan pendidikan di sekolah:
"Yang pertama adalah pendekatan struktural yang memusatkan perhatian pada pengubahan aspek-aspek struktural- birokratik, seperti job descriptions, tatanan birokrasi, pengaturan hubungan antar unit organisasi, gaya kepemimpinan, dan aspek struktur sekolah lainnya. Sedangkan yang kedua adalah pendekatan budaya dengan pusat perhatian pada budaya keunggulan (culture of excellence), yang menekankan pengubahan pada pikiran, kata-kata, sikap, perbuatan dan hati setiap warga sekolah. Pendekatan budaya untuk mengembangkan atau meningkatkan kinerja sekolah akan lebih efektif dibandingkan dengan pendekatan struktural"

(Sastrapratedja, 2001).

Kedua pendapat di atas, mengingatkan pada sejumlah konsep pokok dalam literatur berjudul "Culture Matters: How Values Shape Human Progress" (Harrison \& Huntington, 2000) dimana dalam perkembangannya para ahli ilmu sosial mulai memberikan perhatian pada faktor kultural dalam menjelaskan berbagai realitas di masyarakat yang terkait dengan isu pembangunan, modernisasi, demokratisasi, dan lain-lain. Kemajuan ataupun 
Jurnal Pemikiran Sosiologi Volume 2 No. 1, 2013

Kultur Sekolah

Ariefa Efianingrum

ketertinggalan tidak disebabkan oleh faktor yang berasal dari luar masyarakat, melainkan oleh karena faktor internal dari dalam masyarakat itu sendiri. Masyarakat sendirilah yang memilih untuk maju atau tertinggal.

Faktor internal tersebut tidak lain adalah budaya. Tidak ada definisi tunggal mengenai kebudayaan. Clifford Geertz mendefinisikan kebudayaan sebagai:

"Deskripsi mendalam (thick description) dalam menjelaskan jalan hidup masyarakat (the way of life of a society) yang meliputi: nilai, praktik, simbol, institusi, dan relasi sosial. Kebudayaan juga diartikan sebagai referensi bersama yang memungkinkan bahwa tingkah laku anggota suatu kelompok sosial dapat dipahami, diramalkan, dan diterima oleh anggota lainnya"

(Harrison \& Huntington, 2000)

Pendapat lain menyatakan bahwa rasional, justru mengingatkan kepada kebudayaan dapat mengubah suatu kita bahwa perubahan pada aspek keadaan chaos menjadi kosmos, tersebut tidak sepenuhnya berhasil mengubah suatu keadaan penuh tanpa dukungan faktor kultural. Kultur kekacauan menjadi keteraturan, dan sekolah merupakan faktor kunci yang mengubah suatu keadaan tanpa makna menentukanpencapaianprestasi menjadi jaringjaring makna yang akademik maupun nonakademik, dan penuh arti (Kleden, 1988). Kebudayaan keterlaksanaan proses pembelajaran seringkali dipahami semata-mata sebagai rekayasa sosial untuk mendorong pembangunan ekonomi.
Belum banyak yang mempersoalkan kebudayaan dalam konteks dinamika budaya yang terkait dengan kebudayaan itu secara leluasa. Kebudayaan memiliki kekuatan konstitutif dan dapat memainkan peran untuk transformasi. Kebudayaan juga memiliki kekuatan reflektif yang berperan dalam melakukan legitimasi sosial (Kleden, 1988). Hal yang sama terjadi dan berlaku dalam konteks persekolahan (schooling).

Dalam konteks sekolah, Deal \& Peterson (2011) juga mengungkapkan tentang pentingnya kultur, seperti tersaji dalam literatur "Shaping School Culture" berikut:

"While policymakers and reformers are pressing for new structures and more rational assessments, it is important to remember that these changes cannot be successful without cultural support. School culture, in short, are key to school achievement and student learning"

(Deal \& Peterson, 2011)

Maknanya bahwa kultur sekolah dan pimpinan sekolah memiliki peran simbolik dalam membentuk pola kultural dalam praktik kehidupan di sekolah. Ketika para pengambil kebijakan dan reformis pendidikan lebih menekankan pada pentingnya struktur dan asesmen rasional, justru mengingatkan kepada kita bahwa perubahan pada aspek tersebut tidak sepenuhnya berhasil tanpa dukungan faktor kultural. Kultur sekolah merupakan faktor kunci yang menentukan pencapaian prestasi akademik 
maupun non-akademik, dan keterlaksanaan proses pembelajaran bagi siswa.

Dalam realitas dan praktik pendidikan, upaya perbaikan pendidikan senantiasa dilakukan dalam mewujudkan sekolah yang berkualitas, namun hasilnya seringkali belum sesuai dengan harapan. Seperti dikemukakan oleh Deal \& Peterson (2011) dalam pernyataan berikut ini:

"Too much emphasis has been given in reforming schools from the outside, through policy ad mandate. Too little attention has been paid to how schools can be shape from within, as Roland Barth demonstrates. Teaching staffs and administrators can lead the way to successful cultures where all students learn. It's clearly time to reconsider and rethink the issue and importance of school culture in today's educational environment"

(Deal \& Peterson, 2011)

Pernyataan diatas mengandung arti bahwa upaya perbaikan pendidikan di sekolah selama ini lebih menitikberatkan pada perbaikan faktor eksternal, antara lain melalui aneka perubahan kebijakan pendidikan dan mandat, yang lebih bersifat topdown. Namun belum banyak upaya internal yang dilakukan untuk memperbaiki pendidikan di sekolah, apalagi yang bersifat kultural (bottom-up), menyangkut perubahan mind-set warga sekolah. Sekolah memiliki tanggung jawab untuk meningkatkan kualitas dan memberikan layanan yang terbaik bagi siswa. Para siswa memiliki hak untuk mendapat layanan terbaik yang dapat diberikan oleh sekolah. Para pendidik dapat menjadi pelopor dalam mewujudkan budaya sukses yang menjadi shared values, dimana seluruh siswa dapat belajar. Kini menjadi jelas bahwa isu tentang kultur sekolah adalah penting dan bahkan menjadi nilai inti (the core values) dalam pendidikan saat ini.

\section{B. Kultur Sekolah}

Terdapat sejumlah pengertian tentang kultur sekolah, antara lain yang dikemukakan oleh Deal \& Peterson (2011) berikut ini:

"School culture is the set of norms, values and beliefs, rituals and ceremonies, symbols and stories that make up the persona of the school. These unwritten expectation build up over time as teachers, administratirs, parents, and students work together, solve problems, deal with challenges and, at times, cope with failurues, For examples, every school has a set of expectations about wjat can be discussed at staff meetings, what constitutes good teaching techniques, how willing the staff is to change, and the importance of staff development. School culture is also the way they think their schools and deal with the culture in which they work"

(Deal \& Peterson, 2011) 
Budaya sekolah merupakan himpunan normanorma, nilai-nilai dan keyakinan, ritual dan upacara, simbol dan cerita yang membentuk persona sekolah. Disini tertulis harapan untuk membangun dari waktu ke waktu sebagai guru, administrator, orang tua, dan siswa bekerja sama, memecahkan masalah, menghadapi tantangan dan mengatasi kegagalan. Setiap sekolah memiliki seperangkat harapan tentang apa yang dapat dibahas pada rapat staf, bagaimana teknik mengajar yang baik, dan pentingnya pengembangan staf. Budaya sekolah juga merupakan cara berpikir tentang sekolah dan berurusan dengan budaya dimana mereka bekerja. Sedangkan menurut Schein (Peterson, 2002), budaya sekolah dimaknai sebagai:

"School cultures are complex webs of traditions and rituals that have been built up over time as teachers, students, parents, and administrators work together and deal with crises and accomplishments. Cultural patterns are highly enduring, have a powerful impact on performance, and shape the essays people think, act, and feel"

(Schein, Deal \& Peterson, 2002).

Budaya sekolah merupakan jaringan tradisi dan ritual yang kompleks, yang telah dibangun dari waktu ke waktu oleh guru, siswa, orangtua, dan administrator yang bekerja sama dalam menangani krisis dan prestasi. Pola budaya sangat abadi, memiliki dampak yang kuat pada kinerja, dan membentuk bagaimana orang berpikir, bertindak, dan merasa.
Dalam perjalanannya, sekolah juga memiliki kebiasaan dan upacara-komunal untuk merayakan keberhasilan, untuk memberikan kesempatan selama transisi kolektif, dan untuk mengakui kontribusi masyarakat terhadap sekolah. Budaya sekolah juga meliputi simbol dan cerita yang mengkomunikasikan nilai-nilai inti, memperkuat misi, membangun komitmen, dan rasa kebersamaan. Simbol adalah tanda lahiriyah nilai. Cerita merupakan representasi sejarah dan makna kelompok. Dalam budaya positif, fitur tersebut memperkuat proses pembelajaran, komitmen, dan motivasi, karena menjamin para anggota konsisten dengan visi sekolah.

Menurut Peterson (2002), suatu budaya sekolah mempengaruhi cara orang berpikir, merasa, dan bertindak. Mampu memahami dan membentuk budaya adalah kunci keberhasilan sekolah dalam mempromosikan staf dan belajar siswa. Sedangkan menurut Willard Waller (Deal \& Peterson, 2011), sekolah memiliki budaya yang pasti tentang diri mereka sendiri. Di sekolah, ada ritual yang kompleks dalam hubungan interpersonal, satu set kebiasaan, adat istiadat, dan sanksi irasional, kode moral yang berlaku di antara mereka. Orangtua, guru, kepala sekolah, dan siswa selalu merasakan sesuatu yang istimewa, namun seringkali tak terdefinisikan, tentang sekolah mereka, tentang sesuatu yang sangat kuat namun sulit untuk dijelaskan. Kenyataan ini, merupakan aspek sekolah yang sering diabaikan dan akibatnya seringkali tidak hadir dalam diskusidiskusi tentang upaya perbaikan sekolah. 
Dalam literatur sosiologi pendidikan, kebudayaan sekolah dimaknai sebagai: a complex set of beliefs, values and traditions, ways of thinking and behaving, yaitu seperangkat keyakinan, nilai, dan tradisi, cara berpikir dan berperilaku yang membedakannya dari institusi-institusi lainnya (Vembriarto, 1993). Lebih lanjut dikemukakan bahwa kebudayaan sekolah memiliki unsur-unsur penting, mulai dari yang abstrak/non-material hingga yang konkrit/material, yaitu:

1. Nilai-nilai moral, sistem peraturan, dan iklim kehidupan sekolah.

2. Pribadi-pribadi yang merupakan warga sekolah yang terdiri atas siswa, guru, non teaching specialist, dan tenaga administrasi.

3. Kurikulum sekolah yang memuat gagasangagasan maupun fakta-fakta yang menjadi keseluruhan program pendidikan.

4. Letak, lingkungan, dan prasarana fisik sekolah gedung sekolah, mebelair, dan perlengkapan lainnya.

Sekolah berperan dalam menyampaikan kebudayaan dari generasi ke generasi dan oleh karena itu harus selalu memperhatikan kondisi masyarakat dan kebudayaan umum. Namun demikian, di sekolah itu sendiri timbul pola kelakuan tertentu. Kebudayaan sekolah merupakan bagian dari kebudayaan masyarakat luas, namun mempunyai ciri-ciri yang khas/unik sebagai suatu sub-kebudayaan/sub-culture (Nasution, 1999). Timbulnya sub-kebudayaan sekolah juga terjadi karena sebagian besar dari waktu siswa terpisah dari kehidupan orang dewasa. Dalam kondisi demikian, dapat berkembang pola perilaku yang khas bagi siswa yang tampak dari pakaian, bahasa, kebiasaan, kegiatan-kegiatan, serta upacaraupacara. Sebab lain timbulnya kebudayaan sekolah adalah tugas sekolah yang khas yakni mendidik anak melalui penyampaian sejumlah pengetahuan (kognitif), sikap (afektif), ketrampilan (psikomotorik) yang sesuai dengan kurikulum dengan metode dan teknik kontrol tertentu yang berlaku di sekolah itu. Sebagai sub-kultur, kultur sekolah hadir dalam berbagai variasi dalam praktiknya.

\section{Implikasi Kultur Sekolah dalam Perbaikan Sekolah}

Deal \& Peterson (1999) memperluas kajian yang menunjukkan betapa kultur berpengaruh terhadap berjalannya fungsi sekolah. Berikut ini deskripsi mengenai aspek-aspek kultur sekolah yang berpengaruh terhadap fungsi sekolah:

\section{Visi dan Nilai (Vision and Values)}

Kouzes dan Posner (Locke, et.al. 1991) mendefinisikan visi sebagai berikut: "Vision as an ideal and unique image of the future". Sedangkan Hickman \& Silva mendeskripsikannya sebagai "A mental journey from the known to the unknown, creating the future from a montage of current facts, hopes, dreams, dangers, and opportunities".

Berdasarkan pengertian tersebut, visi merupakan citra ideal dan unik tentang masa depan atau orientasi masa depan terhadap kondisi ideal yang dicita-citakan. Nilai, secara sosiologis/antropologis, dapat didefinisikan sebagai berikut: " $A$ value is a 
conception, explicit or implicit, distinctive of an individual or characteristic of a group, of a desirable which influence the selection from available modes, means, and ends of action"(Kluckhohn dalam Enz, 1986).

Nilai bukan sekedar sebuah preferensi, melainkan merupakan persenyawaan dari pemikiran, perasaan, dan preferensi. Menurut Parsons \& Shils (Enz, 1986), komponen nilai meliputi: kognitif, emosional, dan evaluatif. Sedangkan menurut Harrison \& Huntington (2000), terdapat dua kategori nilai, yaitu nilai intrinsik dan nilai instrumental. Nilai intrinsik merupakan nilai yang ditegakkan tanpa memperhatikan untung/rugi, misalnya: nilai patriotisme. Sedangkan nilai instrumental merupakan nilai yang didukung karena menguntungkan, misalnya produktivitas. Visi misi tujuan dan nilai-nilai dalam budaya merupakan unsur yang penting. Pentingnya tujuan bermakna norma-norma yang positif, dan nilai-nilai yang dipegang teguh untuk menambahkan semangat dan vitalitas untuk perbaikan sekolah.

\section{Upacara dan Perayaan (Ritual and Ceremony)}

Upacara, tradisi, dan perayaan sekolah bermanfaat dalam membangun jaringan informal yang relevan dengan budaya. Momentum-momentum penting di sekolah dapat dirayakan secara sederhana untuk me-recharge esprit de corps yang dimiliki sekolah untuk menggelorakan visi dan spirit sekolah.

\section{Sejarah dan Cerita (History and Stories)}

Sejarah dan cerita masa lalu penting dalam mengalirkan dan memancarkan energi budaya. Fokus pada setiap budaya sekolah adalah aliran sejarah dan peristiwa masa lalu yang turut membentuk budaya berkembang pada masa kini. Dengan kata lain, romantisme masa lalu dapat membangkitkan semangat untuk mewujudkan kejayaan masa depan.

\section{Arsitektur dan Artefak (Architecture and Artifacts)}

Sekolah biasanya memiliki simbol-simbol seperti: arsitektur, motto, kata-kata dan tindakan. Setiap sekolah memiliki lambang/logo sekolah, motto, lagu (mars/hymne), dan seragam sekolah yang mencerminkan visi dan misi sekolah. Pemanfaatan lahan pada area sekolah seperti: dinding kelas, selasar sekolah, dan lorong sekolah untuk memampangkan artefak fisik, efektif dalam menumbuhkan nilai dan spirit utama sekolah, misalnya melalui poster, majalah dinding, spanduk, dan pesan inspiratif lainnya. 
Jurnal Pemikiran Sosiologi Volume 2 No. 1, 2013

Kultur Sekolah

Ariefa Efianingrum

Selanjutnya disajikan sejumlah fakta yang menunjukkan bahwa kultur sekolah memiliki implikasi terhadap upaya perbaikan sekolah, seperti dikemukakan Deal \& Peterson (2011). Namun demikian, dalam praktiknya kultur sekolah seringkali justru terlewatkan dalam upaya perbaikan sekolah antara lain:

1. Culture fosters school effectiveness and productivity (Budaya mendorong terwujudnya efektivitas dan produktivitas sekolah).

Guru dapat berhasil dalam memfokuskan budaya pada produktivitas, kinerja, dan upaya perbaikan. Budaya membantu para guru dalam mengatasi ketidakpastian pekerjaan mereka dengan memberikan fokus pada kolegialitas. Hal ini penting untuk memberikan motivasi sosial dalam suatu pekerjaan yang menuntut mereka siap mengajar tigapuluh anak di ruang kelas. Budaya mendorong, memberi sanksi, dan memberi penghargaan pada tugas profesional untuk meningkatkan ketrampilan mereka.

2. Culture improves collegial and collaborative activities that fosters better communication and problem solving practices (Budaya meningkatkan kegiatan kolegial dan kolaboratif yang mendorong perbaikan komunikasi dan praktik pemecahan masalah).

Di sekolah, budaya menghargai kolegialitas dan kolaborasi. Terdapat iklim yang lebih baik untuk mempertukarkan ide-ide sosial dan profesional, peningkatan dan penyebaran praktik-praktik yang efektif, dan meluas pada pemecahan masalah profesional.

\section{Culture fosters successful change and} improvement efforts (Budaya mendorong upaya keberhasilan perubahan dan perbaikan).

Budaya beracun (toxic culture) mendukung mediokritas dan sikap apatis, yang tidak mungkin mendorong inovasi. Sebaliknya, di sekolah-sekolah yang menganut norma-norma kinerja perubahan, para staf dengan senang hati bereksperimen dengan menggunakan pendekatan baru, menemukan praktik-praktik inovatif untuk memecahkan masalah, dan memperkuat visi pembelajaran yang berfokus pada perbaikan sekolah. Budaya sekolah mendorong pembelajaran dan kemajuan dengan mengembangkan iklim yang kondusif untuk perubahan tujuan, dukungan untuk mengambil resiko dan eksperimentasi, serta semangat masyarakat menilai kemajuan tujuan.

4. Culture builds commitment and identification of staffs, students, and administrators (Budaya membangun komitmen dan identifikasi dari para staf, siswa dan tenaga administrasi).

Orang-orang termotivasi dan merasa berkomitmen pada suatu organisasi yang memiliki makna, nilainilai, sebuah tujuan yang memuliakan. Komitmen tumbuh dengan kuat dan memelihara kultur sosial. Identifikasi diperkuat dengan misi inspiratif yang jelas dan mengkristal yang dipegang teguh. Motivasi diperkuat melalui ritual yang memelihara identitas, tradisi yang mengintensifkan koneksi ke sekolah, dan upacara yang membangun komunitas. 
5. Culture amplifies the energy, motivation, and vitality of a school staff, students, and community (Budaya menguatkan energi, motivasi, dan vitalitas dari staf sekolah, siswa, dan komunitas/masyarakat).

Iklim sosial budaya berpengaruh terhadap orientasi emosional dan psikologis para staf. Dalam sejumlah kasus, sekolah yang memiliki spirit optimis memiliki iklim yang positif, bersemangat, menghargai, dan mendorong. Sebaliknya, dalam sekolah yang pesimis, yang berkembang adalah kultur negatif dan lingkungan sosial yang negatif dan tidak produktif.

\section{Culture increases the focus of daily behavior} and attention on what is important and valued (Budaya meningkatkan fokus pada perilaku keseharian dan perhatian pada apa yang penting dan bernilai/berharga).

Meskipun aturan, job-description, dan kebijakan dapat membentuk dan mempengaruhi perilaku seseorang, namun dalam aturan yang tidak tertulis maupun kebiasaan dan tradisi dalam kehidupan sehari-hari, seringkali justru lebih bermakna dalam mendorong aktivitas dan kemajuan yang berkelanjutan di sekolah. Asumsi-asumsi tersembunyi yang melekat dalam pola budaya lebih intensif. Dengan nilai yang kuat dan bermakna, pekerjaan sehari- hari menjadi lebih berfokus pada isu-isu penting seperti: kualitas pembelajaran, pengajaran yang kontinyu, dan akselerasi belajar bagi seluruh siswa.
Dengan demikian, budaya sekolah memiliki pengaruh terhadap prestasi sekolah, perubahan dan perbaikan sekolah, serta berpengaruh pada pembelajaran siswa. Suatu sekolah dapat bertransformasi dengan membangun kekuatan, tujuan, dan budaya belajar positif, dengan meninggalkan kebiasaan yang negatif dan kontra produktif. Pimpinan sekolah yang senantiasa mengkomunikasikan tujuan bersama dan membangun makna simbolis merupakan kunci untuk membentuk budaya sukses di sekolahnya.

\section{Aneka Praktik Pengembangan Kultur Sekolah}

Kultur sekolah bukan sekedar kultur di sekolah. Kultur sekolah dimiliki oleh tiap-tiap sekolah. Masing-masing sekolah dapat mengembangkan keunikan dan ciri khas melalui kultur sekolah. Oleh karenanya terdapat variasi kultur di sejumlah sekolah. Pengembangan kultur di masing-masing sekolah dapat disesuaikan dengan aspek-aspek yang dianggap penting oleh masing-masing sekolah, seperti: visi-misi, kondisi dan potensi sekolah. Sejumlah sekolah lebih menekankan kultur sekolah yang fokus untuk mendorong pencapaian prestasi akademik. Namun sejumlah sekolah yang lain lebih fokus pada aspek non-akademik. Hal tersebut sangat dimungkinkan, mengingat para siswa yang mendapatkan layanan pendidikan memiliki kecerdasan majemuk (multiple intelligences) yang bervariasi. 
Adapun kultur sekolah yang dapat dikembangkan antara lain yang kondusif bagi pengembangan:

\section{Prestasi Akademik}

Di sekolah yang menghargai prestasi akademik, terjadi proses penciptaan iklim akademik (academic athmosphere) yang bertujuan untuk mencapai prestasi akademik. Prestasi akademik ini biasanya terkait dengan sejumlah mata pelajaran pokok yang dipelajari di sekolah. Sebagian besar orang tua siswa cenderung menghargai prestasi akademik daripada prestasi lainnya.

\section{Non-Akademik}

Prestasi non-akademik juga dapat dikembangkan melalui kultur sekolah yang menghargai prestasi olah-raga, seni, dan ketrampilan lainnya. Nilai-nilai kreativitas dan demokrasi juga dapat dikembangkan melalui kultur sekolah yang memberi ruang (space) yang memadai, sehingga siswa memiliki keleluasaan untuk berpartisipasi, berkreasi, berpikir secara kritis, berperilaku humanis. Selama ini kebanyakan sekolah menganggap penting prestasi akademik siswa. Profil kecerdasan majemuk siswa yang bervariasi seringkali terabaikan. Padahal dalam realitasnya, kesuksesan seseorang tidak hanya ditentukan oleh prestasi akademik yang telah dimiliki, melainkan juga disebabkan oleh prestasi non-akademiknya.

\section{Karakter}

Karakter berkaitan dengan moral dan berkonotasi positif. Pendidikan untuk pembangunan karakter pada dasarnya mencakup pengembangan substansi, proses dan suasana atau lingkungan yang menggugah, mendorong, dan memudahkan seseorang mengembangkan kebiasaan yang baik. Karakter bersifat inside-out,maksudnya bahwa perilaku yang berkembang menjadi kebiasaan baik ini terjadi karena adanya dorongan dari dalam, bukan karena paksaan dari luar (HB X, 2012). Adapun variasi nilai karakter yang dapat dikembangkan melalui kultur sekolah antara lain: yang kondusif bagi pengembangannilai-nilai religius, nilai demokrasi, kedisiplinan, kejujuran, ramah anak, anti kekerasan, dan lain-lain.

\section{Kelestarian Lingkungan Hidup}

Sejumlah sekolah di berbagai level (SD, SMP, SMA) mendapatkan penghargaan dan predikat sebagai sekolah adiwiyata, yaitu sekolah menjaga kelestarian lingkungan hidup. Penghargaan tersebut perlu diapresiasi dalam menstimulasi terwujudnya sekolah berwawasan lingkungan. Namun demikian, predikat sekolah adiwiyata tidak muncul dengan sendirinya tanpa diupayakan melalui pengembangan kultur sekolah ramah lingkungan. Sejumlah sekolah yang fokus dalam pengembangan sekolah hijau (green school) memiliki visi-misi yang berorientasi pada kehidupan dan kondisi lingkungan masa depan yang lebih baik dan berkelanjutan (sustainability). Untuk mewujudkannya, memerlukan komitmen bersama seluruh warga sekolah dalam pengembangan kultur sekolah yang ramah lingkungan. 
Demikian tadi sejumlah contoh kultur sekolah yang dapat dikembangkan oleh tiap-tiap sekolah. Masih terbuka bagi sejumlah alternatif lain sesuai karakteristik dan kreativitas masing-masing sekolah. Program sekolah dalam menyelenggarakan pendidikan dan mengembangkan kultur sekolah dapat bervariasi karena tidakada model tunggal. Setiap sekolah memiliki tujuan umum pendidikan yang relatifsama (universal), namun sebagai subkultur, setiap sekolah dapat mengembangkan kultur sekolah yang khas (relatif) sesuai dengan potensi yang dimiliki oleh institusi sekolah. Sub-kultur tersebut biasanya identik dengan kultur di masyarakat yang lebih luas. Dengan adanya variasi tersebut, setiap sekolah memiliki peluang untuk menjadi sekolah unggul, dengan keunggulan masing-masing yang khas. Setiap sekolah bahkan dapat saling mengisi secara kolaboratif, bukannya bersaing secara kompetitif. Semua kembali kepada bagaimana dan kemana pimpinan sekolah akan membawa dan mengarahkan sekolahnya. Bukankah pimpinan sekolah memiliki peran sentral dalam membagikan nilai (shared values) dan mengkomunikasikan visi-misi sekolah kepada seluruh warga sekolah?

\section{E. Penutup}

Kultur sekolah memiliki peran simbolik dalam membentuk pola kultural dalam praktik kehidupan di sekolah. Kultur sekolah merupakan faktor kunci yang menentukan pencapaian prestasi akademik maupun non akademik, dan keterlaksanaan proses pembelajaran bagi siswa. Kultur sekolah meliputi faktor material yang tangible dan non- material yang intangible. Realitas menunjukkan bahwa kunci keberhasilan pendidikan seringkali justru terletak pada faktor yang tak terlihat. Karenanya, menekankan perbaikan pendidikan di sekolah pada proses restrukturisasi semata, tidak lagi memadai. Namun demikian, restrukturisasi yang bersifat struktural dan rekonstruksi yang bersifat kultural tidak perlu saling menegasikan dalam praktiknya.

Dalam pengembangan kultur sekolah, terdapat aneka pilihan alternatif yang dapat disesuaikan dengan visi-misi dan kondisi sekolah, serta profil siswa dalam aneka kecerdasan majemuk Sebagai sub-kultur, setiap sekolah dapat mengembangkan kultur sekolah yang khas sesuai dengan potensi yang dimiliki, yang bisa jadi identik dengan kultur masyakarat yang lebih luas. Dengan adanya variasi tersebut, setiap sekolah memiliki peluang yang sama untuk membanggakan keunggulan sekolah masingmasing yang khas. Semua ini tergantung pada peran pimpinan sekolah yang dapat menggerakkan dan mengkomunikasikan visi-misi sekolah kepada seluruh warga sekolah. 


\section{Daftar Pustaka}

Deal, Terrence E. \& Peterson, Kent D. 1998. "How Leaders Influence the Culture of Schools?". Educational Leadership, Sept. 1998, Vol. 56, Number 1, Pages 28-30. 1999. Shaping School Culture: The Heart of Leadership. San Fransisco: JosseyBass Publishers.

2011. Shaping School Culture: Pitfals,

Paradoxes, \& Promises. San Fransisco: Jossey-Bass.

Enz, Cathy A. 1986. Power and Shared Values in the Corporate Culture. Michigan: UMI Research Press.

Harrison, Lawrence E. \& Huntington, Samuel P. 2000. Culture Matters: How Values Shape Human Progress? New York: Basic Books.

HB X. 2012. Menggagas Renaisans Pendidikan Berbasis Kebudayaan. Makalah Keynote Speech Kongres Pendidikan, Pengajaran,dan Kebudayaan. Balai senat UGM, 7 Mei.

Kleden, Ignas. 1988. Sikap Ilmiah dan Kritik Kebudayaan. Yogyakarta: LP3ES.

Locke, Edwin A. et.al. 1991. The Essence of Leadership: The Four Keys to Leading Successfully. New York: Maxwell Macmilan Publishing.

Peterson, Kent. D. 2002. Positive or Negative? National Staff Development Council.
Sastrapratedja. 2001. "Budaya Sekolah". Majalah Ilmiah Dinamika Pendidikan, No. 2/Th. VIII, November, Hal. 1-17.

Suyata. 2000. Refleksi Sistem Pendidikan Nasional dan Mencerdaskan Kehidupan Bangsa. Paper dalam Pertemuan Pokja Sistem Pendidikan Nasional untuk Mencerdaskan Kehidupan Bangsa. 